\title{
Open System Condition Serpentinization of Host-rock Magnesite in Süleymaniye, Tutluca and Margı Region of Eskişehir, NW Turkey
}

\author{
Asuman Kahya ${ }^{1, *}$, Mustafa Kuşcu ${ }^{2}$ \\ ${ }^{1}$ General Directorate of Mineral Research and Exploration, Turkey \\ ${ }^{2}$ Geology Department, Suleyman Demirel University, Turkey
}

Copyright $\bigcirc 2016$ by authors, all rights reserved. Authors agree that this article remains permanently open access under the terms of the Creative Commons Attribution License 4.0 International License

\begin{abstract}
Host rock of magnesite occurrences in three areas (Süleymaniye, Marg1, Tutluca) are the altered peridotite which on the northernmost outcrops of the İzmir-Ankra suture zone. Magnesite is formed in the cracks and fractures of highly altered harzburgite in these three areas. Chrysotile and lizardite are the abundant serpentinite mineral and orthopyroxene, olivine, magnetite, talc, brucite and chromite consist of these rocks which have mesh to hourglass texture. Source of $\mathrm{Mg}^{+2}$ for magnesite formation is coming from serpentinite. During serpentinization processes $\mathrm{H}_{2} \mathrm{O}$ and $\mathrm{CO}_{2}$ input mineralogic structure and form mineral transform. $\mathrm{H}_{2} \mathrm{O}$ content in system increases, $\mathrm{MgO}, \mathrm{CaO}$ and $\mathrm{SiO}_{2}$ content decreases because of remove the systems. According to mineralogic association serpentinization of harzburgite occurs low temperature below $350^{\circ} \mathrm{C}$ and represents the open system serpentinization condition. These rocks show positive $\mathrm{La}, \mathrm{Nd}, \mathrm{Eu}, \mathrm{Ho}, \mathrm{Tm}, \mathrm{Lu}$ anomalies but negative $\mathrm{Ce}, \mathrm{Pr}, \mathrm{Sm}, \mathrm{Gd}, \mathrm{Er}, \mathrm{Yb}$ anomalies to chondrite/normalize diagram. REE content of serpentinite are consumed according to chondrite. According to mineralogical and geochemical properties is these rock related to the SSZ type ophiolities.
\end{abstract}

Keywords Host-rock Magnesite, Serpentinite, Geochemistry, Eskişehir

\section{Introduction}

Study areas are located in the SSZ-type ophiolites in the İzmir-Ankara suture zone (Figure 1). Suture zones are mostly characterized by outcrop of ophiolite complexes, their fragments and the serpentinite melanges. Since the description of the formation of the supra-subduction zone (SSZ) type oceanic crust at the eastern part of İzmir-Ankara Suture Belt [1,2], İzmir-Ankara oceanic basin is considered to begin to close with an intra-oceanic subduction $[1,3,4,5]$. One of the most important parameters that control the types of ophiolite which formation in different environments such as mid-ocean ridge, back-arc spreading center and supra-subduction zone (SSZ) ophiolites is the rate of spreading center [6]. Ophiolites which form at fast spreading centers have a strongly depleted residue harzburgite [7], whereas those that form in slow spreading center and continental ridge environments have a weakly depleted residual lherzolite [7]. Harzburgites of MORB types ophiolities generally less depleted than harzburgites of SSZ-type ophiolities and contain more than the average of Al, $\mathrm{Ca}$ and $\mathrm{Ti}$ [8]. [9] indicated that meteoric groundwater is the main factor in serpentinization and lizardite-chrysotile serpentinite minerals formed at lower temperatures than antigorite minerals. Again same researchers stated that ocean-floor serpentinites have a uniform isotopic ratio and ocean water also plays a role in the process of formation of it. $[10,11]$ marked that serpentinites can be formed also hydrotation of mantle peridotites which rising under ridge with juvenil water. Chrysotile, antigorite and lizardite are primary serpentine minerals. Other secondary minerals are magnesite, talc, tremolite-actinolite, chlorite and magnetite. Serpentine minerals occur due to metasomatism of $\mathrm{Mg}$-silicate in particular olivine and pyroxene minerals.

$4 \mathrm{Mg}_{2} \mathrm{SiO}_{4}+4 \mathrm{H} . \mathrm{OH}+2 \mathrm{CO}_{2}=>2 \mathrm{Mg}_{3} \mathrm{SiO}_{5}(\mathrm{OH})+2 \mathrm{MgCO}_{3}$ Olivine Serpentine

With this change rock receive water and volume increases in closed system. Volume increase due to the replacement of bulk (massive) cause a brigth appearance of crack surface. Serpentinization occurs in relation to the conditions of strong reduction, $\mathrm{H}_{2}$ leads to the formation of it, fluid $\mathrm{pH}$ varies between 3 (high temperature) and 12.5 (low temperature) and it is the lowest of $\mathrm{SiO}_{2}$ among terrestrial silicate systems. [12-25] Effective physical condation, formation of minerals and these minerals are represented by $\mathrm{P} / \mathrm{T}$ ranges during the 
serpentinization of ultramafic rocks are as follows: Chrysotile and lizardite are low-grade serpentine minerals and usually occurs in the lower level of greenschist facies. Antigorite is especially greenschist/blueschist and low-amphibolite facies serpentine mineral [26]. Association of brucite + lizardite has been observed under very low temperature and pressure conditions [27]. According to [13], lizardite-chrysotile serpentinites may occur at temperatures lower than $350^{\circ} \mathrm{C}$ but antigorite may be stable up over $500^{\circ} \mathrm{C}$. Lizardite-chrysotile togetherness is stable under 400 to $440{ }^{\circ} \mathrm{C}$ [28]. We can say that in this case, the conversion temperature of serpentinites minerals in study area reaches values of amphibolite facies. Serpentinization is divided into two systems such as open and closed system conditions. Calcite, magnesite, amorphous silica, chrysolitile, brucite deposit in open system conditions and these indicates that fresh water is effective in serpentinization of the ultramafic rocks. Aim of this study investigate the properties of open system conditions serpentinization and temperature of serpentinization on serpentinized harzburgite that host rock of magnesite in SSZ-type ophiolites

\section{Material and Method}

During field studies, 30 samples from the host rock of magnesite in the Sülaymaniye, Margı and Tutluca areas of them were collected. Thin section was made all of the harzburgite sample. Mineralogical determination of harzburgites was done by transmitted and reflected-light microscope and X-Ray diffraction in General Directorate of Mineral Research and Exploration (Turkey). XRD analysis was performed with Philips PW 3710/1830 in Mineralogical Researches Laboratories in General Directorate of Mineral Research and Exploration. 15 samples were chosen for analysis of major, trace and rare earth element content (Table 1) and samples were conducted at the ACME Analytical Laboratories Ltd., Canada, using ICP-MS, Fire Assay and ICP-ES methods.

\subsection{Regional Geology}

Study areas are located in the province of Eskişehir in Northwest Anatolia Region. Tavşanli Zone which study area is located in the northern edge of the Anatolide-Tauride Platform in Western Anatolia and, in the north contact with Pontides along the İzmir-Ankara suture; in the south is located on the tectonically metamorphic rocks of the Afyon Zone (Figure 1). The study areas are situated within the belt stretching from Izmir to Ankara which is called IzmirAnkara suture by [29]. This belt consists of ophiolitic melanges and ophiolitic rocks of widely spread. The study areas are located on the ultramafic units which host rock of cryptocrystalline magnesite formation studied by [30] around Sülaymaniye (Mihallıcckk), Marg1 (Dağküpkü) and Tutluca. According to the evidence all radiolaria Triassic age reflects the age of the İzmir-Ankara branch of Neotethys and the İzmir-Ankara oceanic plate rifting not subducted until Cenomaniyen [31]. After the definitions the formation of supra-subduction zone SSZ type oceanic crust in the east part the İzmir-Ankara suture zone $[1,2]$, it is agreed that İzmir-Ankara oceanic basin began to close by intra oceanic subduction $[1,3,4,5,31]$. Amphibolities in the İzmir-Ankara Suture (IAE) Zone have the oldest radiometric ages between $101 \mathrm{Ma}[31,32]$ ve $90 \mathrm{Ma}[31,33]$ and indicate that intra-oceanic subduction started in the Albian [31] and this data is compatible with the Late Santonian-Campanian age which stated by [5]. Spreading is last until the beginning of the Late Cretaceous according to the age data obtained from fragments of SSZ-type oceanic crust, MORB-type and related to the spreading within the Izmir-Ankara Sutur Zone; SSZ-type oceanic crust started to formation probably in the Late-Early Cretaceous but definitively lasted until early Santonian [31]. Occurrences of ophiolitic melange in the trench of dipping north of IAE may be starting in early Cretaceous time, the collision with before the Campanian continued until late of Middle Lutetian [34, 35].

\subsection{Geology}

In Süleymaniye area, the geological units are the Karkın Formation, ultramafic unit, the Porsuk Formation. The Karkın Formation is composed of metaconglomerate, metasandstone and phyllite of the Triassic age. The formation includes a recrystallized Lower Carboniferous-Upper Permian limestone block [30, 36]. An ultramafic unit consisting of serpentinized peridotite and listvenite, overlies the tectonically metadetritic unit of the Karkın Formation. Ultramafic unit is a host rock of magnesite deposits. The Middle-Upper Miocene Porsuk Formation rests unconformably on the ultramafic unit and is composed of a conglomerate-limestone unit, limestone and marl-clay units. Silicified serpentinite (listvenite) is located at the top, and usually surface along of fractures and part of the high area. This unit is massive and rigid structures observed in tile-red, burgundy, brown color (Figure 2). Ophiolitic rocks are mainly serpentinized peridotites and listvenite $[30,36]$. Serpentinized peridotites outcrop mainly in the 1-2 km south of Doğray, Süleymaniye, Yalımlı villages. Listvenite take place especially at the top of the small topographic highs (namely in the west of the Bükadas1, Hamam, Kızıl, Karakaya, Sarıkaya, Kışlacık hills and around Süleymaniye village). Serpentinized peridotites are mainly sheared at the lowermost part of the ultramafic bodies. Listvenite occurences in brown, reddish brown, violet colors are observed to the upwards, especially along fracture zones (Figure 2).

Marg1 is located in the north-east of Eskişehir, between Marg1-Taycılar-Sepetci. Triassic aged Sömdiken Metamorfites forming the basement of the region composed of Sömdiken gneiss and Sömdiken marble [30, 36]. Gündüzler Melange overlies tectonically Sömdiken 
metamorphites. These formations from bottom to top are mudstone-radiolarite, metadetritic and crystallized limestone and each unite has tectonic contact with each other. Ophiolites (Karabayır ophiolite) comprise peridotites, diabase and listvenite. This unit is called Dagküplü Complex around Gündüzler-Yakayıklı village in North of Eskişehir [30, 37]. Middle-Upper Miocene Porsuk Formation rest unconformably on the former units and comprise of conglomerate-sandstone ( $\mathrm{Np} 1)$, marl-clay (Np2), limestone (Np5) members. Karabayır ophiolite outcropping around Marg1-Taycilar-Basören villages include mainly peridotites, diabase, listvenite. Peridotites are mainly in harzburgitic composition. This serpentinized peridotite is a host rock of magnesite deposits and chromite deposits. Magnesite deposits previously exploited but chromite is run as open and closed pit (Figure 3).

Tutluca area is located at the south-west of Eskişehir. Triassic aged İnonu metamorfites consisting mainly of blueschist facies metamorphic rocks and marble form the basement in the study. Ophiolitic Complex rest on tectonically Inonu metamorphite and represented by peridotite and meta-gabbros. This peridotite is a host rock of magnesite and magnesite deposits is run as open pit. Pliocene aged Ilica formation overlies unconformity former units and is composed of conglomerate-sandstone (pli), basalt (PIB), andesite ( $\alpha$ ). All of these units cover unconformably by alluvial deposits [30, 37]. (Figure 4).

\section{Petrography}

Host rock of magnesite is harzburgite which consist of serpertine, olivine, orthopyroxene, brucite, chromite and magnetite \pm chlorite minerals and effected serpentinization procces. Harzburgites are generally show a brown in colour because of serpentinization. Serpentine crystallized in veins, at olivine-orthopyroxene grain boundaries, and expense of olivine (mesh texture). The mineral nomenculature used here according to [38]. Abundant serpentinite mineral are chrysotile, lizardite and very lesser amounth of antigorite mineral by XRD analysis. Rock become a mesh texture because of extensive serpentinization. Chrysotile form below $250^{\circ} \mathrm{C}$ and product of alteration and degradation of ultramafic rocks [26]. Olivines form anhedral crystals and have variable sizes (from $0.5 \mathrm{~mm}-2 \mathrm{~mm}$ ), showing very crack and serpentinizations occur in this cracks and olivines lost primary future also magnetites which is opaque minerals occur in cracks of some samples in orthopyroxene and olivine (Figure 5a, c). Olivines show triple-junction grain boundaries. Some of the olivine have kink-band geometry. [39] explained that the microstructure and kink-band geometry of olivine indicates that these minerals exposed to the high-temperature plastic deformation. Relict olivine which represent the interaction between olivine and magma is in orthopyroxene. Secondary talk and Mg-clorite occur in fracture within olivine. Orthopyroxenes are euhedral-subhedral minerals found in porphyroclasts, the average grain sizes range from 1-2 mm. Bending of cleavages because of deformation are apparent. Most of orthopyroxene minerals have diopside (clinopyroxene) exsolutions which form along cleavages like a thin lamellae were observed (Figure 5a). This clinopyroxene exsolutions lamellae which in orthopyroxene indicate that formation of these minerals under high pressure. Magnetites decomposition form in cracks of these minerals (Figure 5b, c). In addition, transitions to talc minerals in some cracks of orthopyroxenes minerals were observed. Chromite crystals form euhedral to subhedral minerals and mostly grain size $0.5 \mathrm{~mm}-1 \mathrm{~mm}$, brown-black, generally show a pull-apart fracture. Some of these are rounded or elongate due to development of foliation and show a oriantation some sample have orientation. Assemblage of chrysotile and brucite occur from $\mathrm{Fe}-$ poor $\mathrm{Fo}^{90}$ composition olivine and after reaction $\mathrm{Fe}$ show dispersion as magnetite [40]. It is stated that upper temperature limit of this mineralogic assemblage aproximately $390^{\circ} \mathrm{C}\left( \pm{ }^{\circ} \mathrm{C}\right.$ and 100$)$. Most of the serpentinite contain magnetite. Ferroan magnetite occur exchange of Fe-Mg between olivine and serpentinite during the serpentinization in low $\mathrm{SiO}_{2}[25,40]$. Magnetite not important only understand the geochemistry of serpentinite it is important to understand the magnetization of serpentinite (Example; formation of magnetite relate to reduction condation and characterize the active serpentinizing condition). In particular, [41] argued that between the beginning of serpentinization (shown by a decrease in density) and occurring the modal of the magnetite (demonstration of the sensitivity of magnetic with susceptibility) is a stop, this situation delayed the formation of magnetite and a result of multi-stage serpentinization. [42] stated that in their study magnetites in serpentinites occurr two-stage process as oxidation-silicification of brucite and oxidation-desilication of Fe-serpentinite. [43], defined that his study in Guleman serpentinities, some of the magnetites occur with iron ions released from the structure of silicate minerals during serpentinization and then entering the structure of chromite, some of magnetites also occur with oxidation of iron ions and this stated along the line of cracks in developed serpentinization like anhedral grain. The formation of magnetite is formed by release of silica from serpentine $\left(\mathrm{Fe}_{3} \mathrm{Si}_{2} \mathrm{O}_{5}(\mathrm{OH})\right)$ composition and product of reduction environment. [44] stated that in their study in weak serpentinized harzburgite which opx rich in New Caledonya, formation of magnetite related to the gradual change at silica activity during serpentization process. Opx-rich serpentine has richer silica than serpentinite related to serpentization of olivine. [43] indicate that in their analyses the Opx was hydrated by a reaction in which the $\mathrm{Fe}$ and $\mathrm{Mg}$ were transferred directly to the serpentine. All the iron is the accepted ferrous and the reaction can be modeled as follow [44].

$$
\begin{aligned}
& \text { 1.5 } \mathrm{Fe}_{0.26} \mathrm{Mg}_{1.74} \mathrm{Si}_{2} \mathrm{O}_{6}+2 \mathrm{H}_{2} \mathrm{O}= \\
& =\mathrm{Fe}_{0.39} \mathrm{Mg}_{2.61} \mathrm{Si}_{2} \mathrm{O}_{5}(\mathrm{OH})_{4}+\mathrm{SiO}_{2}
\end{aligned}
$$

If some of the Fe was ferric, very low silica derived from 
this reaction. Silica which derived from this reaction is consumed by serpentinization with olivine. Here as reaction.

$$
\begin{gathered}
3.084 \mathrm{Mg}_{1.8} \mathrm{Fe}_{0.2} \mathrm{SiO}_{4}+0.916 \mathrm{SiO}_{2}+5.89 \mathrm{H}_{2} \mathrm{O}= \\
2 \mathrm{Mg}_{2.775} \mathrm{Fe}_{0.225} \mathrm{Si}_{2} \mathrm{O}_{5}(\mathrm{OH})_{4}+0.056 \mathrm{Fe}_{3} \mathrm{O}_{4}+1.89 \mathrm{H}_{2}
\end{gathered}
$$

$\mathrm{Fe}$ is dissolved serpentinite in high silica activity environment, but in with low silica activity environment silica is release from serpentine and $\mathrm{Fe}$ leaves to form a magnetite in. [44], ssimultaneous formation of olivine which dissolved temperatures above $330^{\circ} \mathrm{C}$, serpentine, magnetite and dihydrogen depends on the silica source of external. $<330^{\circ} \mathrm{C}$ at low temperatures, the formation of hydrogen which is simplifying by brucite, serpentine which form olivine dissolution, magnetite and brucite does not require additional silica. Temperature range of the observed iron distribution in serpentine and brucite is compatible with the formation temperature $<150$ to $250^{\circ} \mathrm{C}$ [45]. In the study area harzburgites are subject to serpentinization, so the rock is rich in terms of the content of orthopyroxene, $\mathrm{Fe}$ and $\mathrm{Mg}$ directly enter into the serpentinite which hydration with ortopyroxene. Silica released this process consumed with the serpentinization of olivine and Fe forms the magnetite.

\section{Geochemistry}

Whole rock chemical analysis of serpentinized harzburgite in the study area are given in Table 1. Los ignation LOI values 23.2-6.5 wt $\%$ and higher water contents of the investigated rocks shows extensive serpentinization of olivine and orthopyroxene. $\mathrm{SiO}_{2}$ and $\mathrm{MgO}$ are high and variable (32.76-52.08 and 29.59-38.13 wt $\%$, respectively). $\mathrm{Al}_{2} \mathrm{O}_{3}$ content (0.11-0.92 wt\%) and $\mathrm{CaO}(0.10-7.58 \mathrm{wt} \%)$ content of host rock is low and indicate that a felspar and clinopyroxene are absent in it. $\mathrm{Na}_{2} \mathrm{O}(0.01-0.05 \mathrm{wt} \%)$ and $\mathrm{TiO}_{2}(<0.01 \mathrm{wt} \%)$ are very low. $\mathrm{MgO}, \mathrm{CaO}$ and $\mathrm{SiO}_{2}$ content of serpentinized harzburgite in study areas show a clear negative correlation with $\mathrm{H}_{2} \mathrm{O}$ content (Figure $6 \mathrm{a}, \mathrm{b}, \mathrm{c}$ ). As shown in Figure 6b, there are weak negative correlations of $\mathrm{CaO}$ with $\mathrm{H}_{2} \mathrm{O}$. Such a characteristic is common to serpentinized harzburgites. In the system, $\mathrm{H}_{2} \mathrm{O}$ increases, whereas $\mathrm{MgO}, \mathrm{CaO}, \mathrm{SiO}_{2}$ content decreases. In the study area, harzburgites are mainly altered to serpentine. For this reason rocks are enriched in orthopyroxene interms of orthopyroxene. By hydration of orthopyroxene, $\mathrm{Fe}$ and $\mathrm{Mg}$ enter structure of serpentine. The silica released from orthopyroxene is used in serpentinization of olivine. The average composition of $\mathrm{Ni}$ is $2110 \mathrm{ppm}$ in ultramafic rocks representing the oceanic crust [46] and the average of $\mathrm{Cr}$ is $3140 \mathrm{ppm}$ in it [47]. Ni values of serpentinites are in the range of 2781-1041 ppm, suggesting a small amount of enrichment. According to the chondrite normalized REE diagram $\mathrm{Ce}, \mathrm{Pr}, \mathrm{Sm}, \mathrm{Gd}, \mathrm{Er}, \mathrm{Yb}$ showed a slight negative anomaly while $\mathrm{La}, \mathrm{Nd}, \mathrm{Eu}, \mathrm{Ho}, \mathrm{Tm}, \mathrm{Lu}$ showed a slight positive anomaly (Figure 7a). [47] stated that positive $\mathrm{Eu}$ anomaly of Pindos dunite and Troodos harzburgite, $\mathrm{Eu}^{+2}$ preferential mobility of the process of serpentinization, shows a lack of plagioclase. Primitive mantle show the same abundance chondrite meteorite [48]. In Chondrite and N-type MORB normalized diagram (Figure 7a, b [49]), the serpentinites of the Süleymaniye, Marg1 and Tutluca areas show very depleted according to REE quantities. Rare earth element contents of ultramafic rocks are very low in ordinary conditions and it is under-chondrite values. At the same time, heavy rare elements (HREE) values in these rocks are evident relative the high values according to the light rare earth element (LREE) values and has a connection of LREE/HREE $<1$ [50]. Serpentinites in the study areas are LREE/HREE $<1$ ratio. Enrichment of the HREE elements is observed as a result of alteration and metamorphism of ultramafic rocks, this event as a mobilization of this elements. This situation is acceptable of serpentinizations. MORB-type ophiolites generally less consumed then SSZ-type ophiolite and contain more $\mathrm{Al}, \mathrm{Ca}$ and $\mathrm{Ti}[8,51]$. Study area serpentinites showed a similar feature of SSZ-type ophiolites according to $\mathrm{Cr}-\mathrm{TiO}_{2}$ diagram (Figure 8, [52].).

\section{Discussion and Conclusions}

Serpentinized harzburgite is a magnesite host rock which samples were taken from them to study petrographic and mineralogical characteristics, geochemical properties. Harzburgites has turned into serpentine mineral with $80-90 \%$ volume because of extensive serpentinization. Rock has transform to $70 \%$ serpentine mineral in volume is sufficient for naming the serpentine [53]. Serpentinization, initially like that fine-reticulate veins of minerals by the edges and cracks starts from the cleavage of minerals and gradually changes the whole texture of the rock. In harzburgites (study areas) which commonly composed of orthopyroxene and olivine, olivine beginning to serpentization from edges and cracks then developed extensively sieve texture while same sample has an hour glass texture. Residue olivine minerals found in the center of sieve texture in progresive serpentinized sample. Orthopyroxenes are generally protected the crystal form and the boundaries and transform serpentine mineral by substitution in cleavage and cracks. The presence of primary mineral like a residual minerals expression us essential water to complete the transformation of mineral in not adequate for this part but formation mineral give us a information about metamorfism efect. Identification of primary rock can be done with the help of the residue minerals. By means of antigorite mineral commonly found in serpentinite, these rocks has been exposed to the effects of hydrothermal metamorphism in some places up to $500^{\circ} \mathrm{C}[54,55]$. At the same time the presence of antigorite minerals and rock has dump texture like a needle shape show the rock exposed to the effects of regional metamorphism in greenschist facies metamorphism [56]. The antigorit mineral is not common is very small amounth in the study areas. Presence of antigorite represent 
the early serpentinization temperature $\mathrm{T}>300^{\circ} \mathrm{C}$ and reflect a rock-dominant serpentinization (closed system serpentinization) [57]. [58] and [59] explained that depleted REE contents of serpentinite and listvenites is associated with alteration product of depleted MORB. REE content of the serpentinized harzburgites in the study area are depleted so we say that alteration of marine and the atmosphere water is exist. [59] show that negative Ce anomaly is evidence of the balance between REE and the sea water samples and similar to the sea water. The negative $\mathrm{Ce}$ anomaly in the serpentinized harzburgite of the study area has demonstrated that serpentinization is associated with meteoric and hydrothermal solution and also sea water in light. Petrographic features, $\mathrm{Al}, \mathrm{Ca}$ and $\mathrm{Ti}$ contents, the REE content of the study area is similar future of SSZ tectonic features of region. According to the mineralogical composition of chrysotile/lizardite are common serpentine mineral and antigorite mineral is very little minerals, magnetite presence can we said that during serpentinization temperature lower than $350^{\circ} \mathrm{C}$ and rise in places. We can say that in the beginning serpentinization process initially closed system environment serpentinization conditions is current, then changing the system condation and then open system environment serpentinization is dominate. We can say that effective $\mathrm{CO}_{2}$ of magnesite occurrences in the fractures and cracks of the ultramafic rocks enter into the system from the atmosphere and the surrounding carbonate rock is the evidence of the open system conditions of serpentinization.
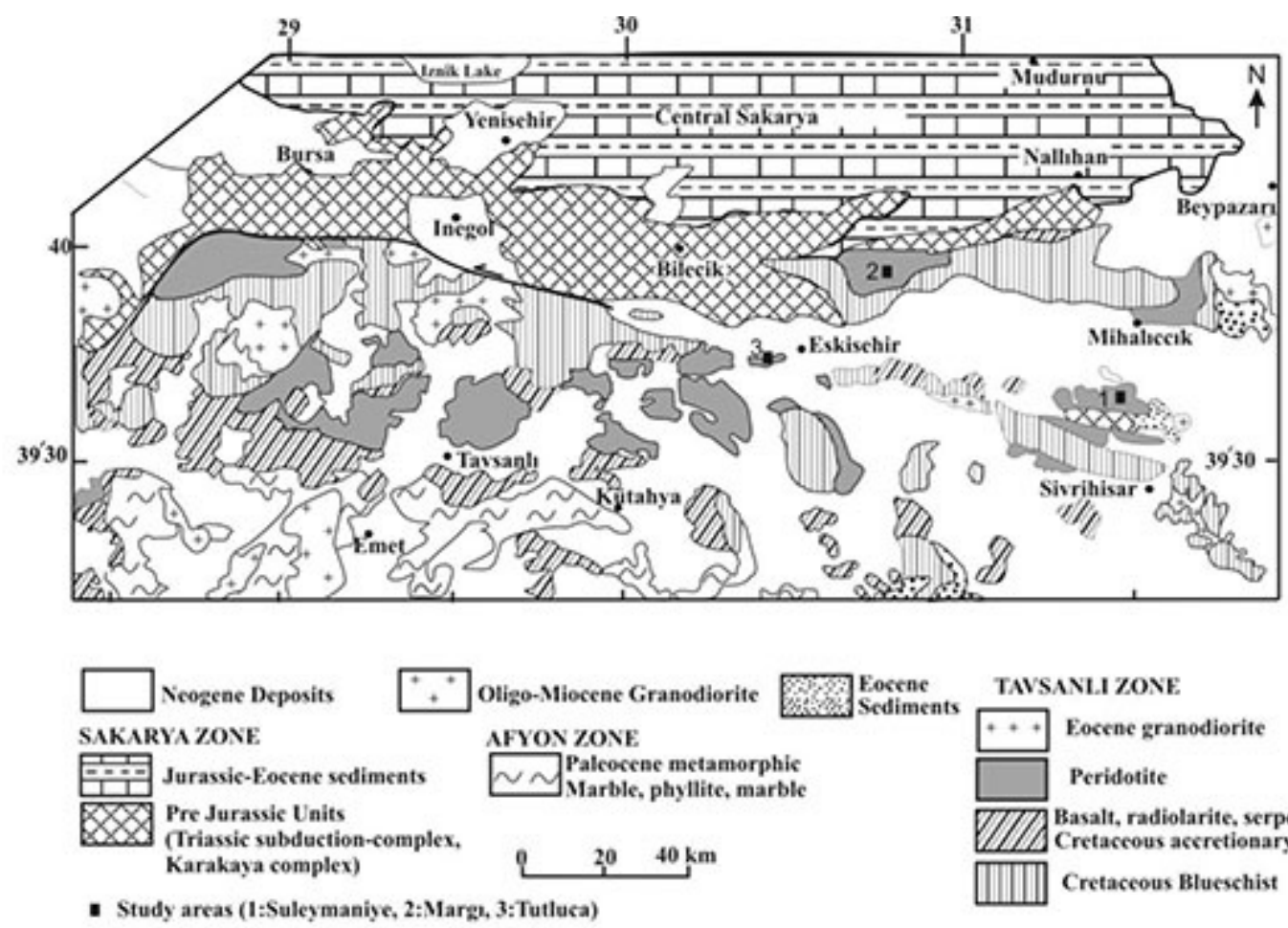

TAVSANLIZONE

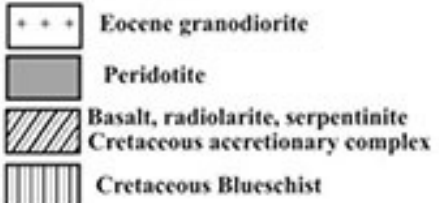

Figure 1. Tectonic map of Tavsanlı Zone [5, 30] 

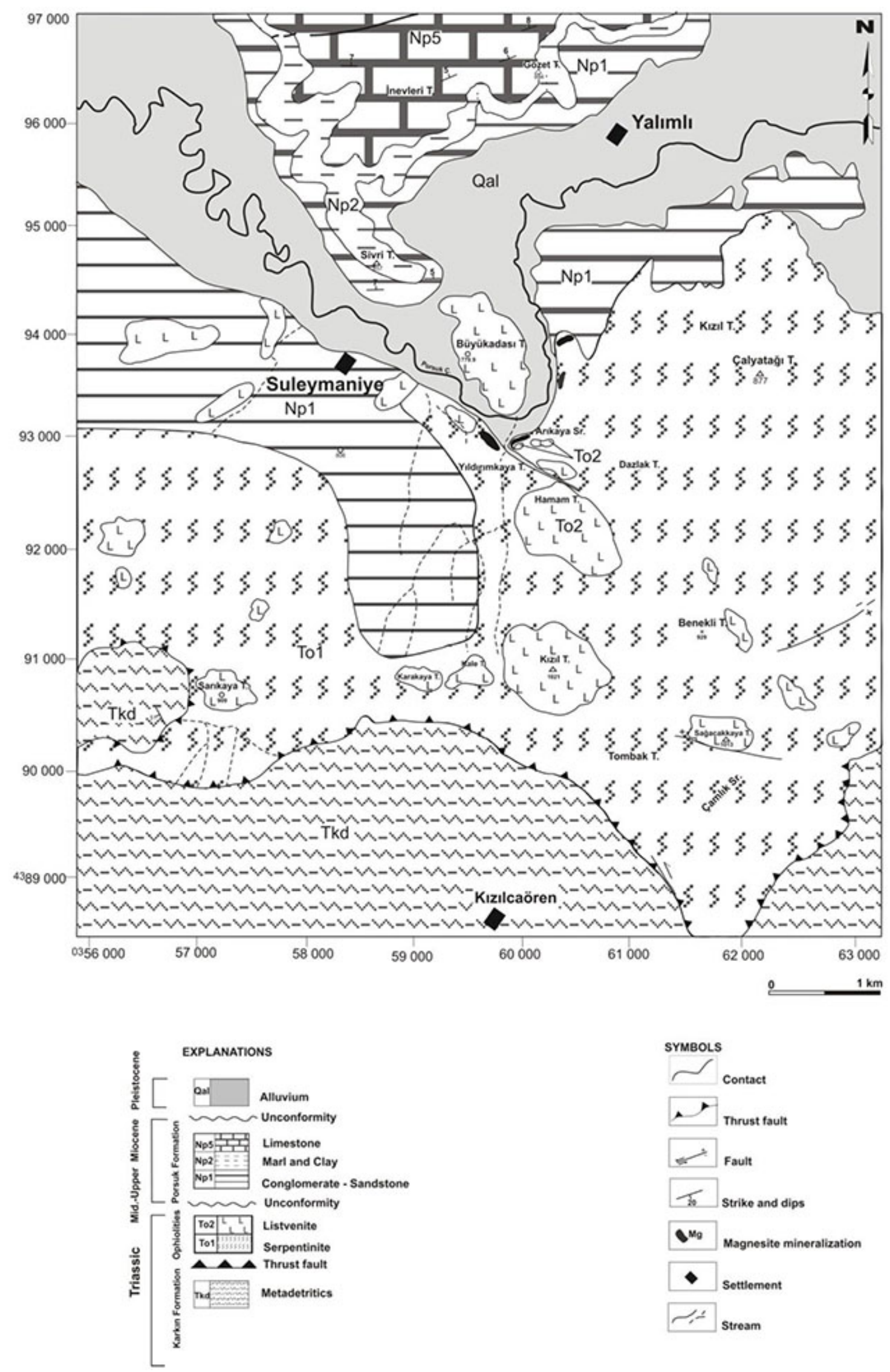

Figure 2. Geologic map of Süleymaniye area [30, 36]. 


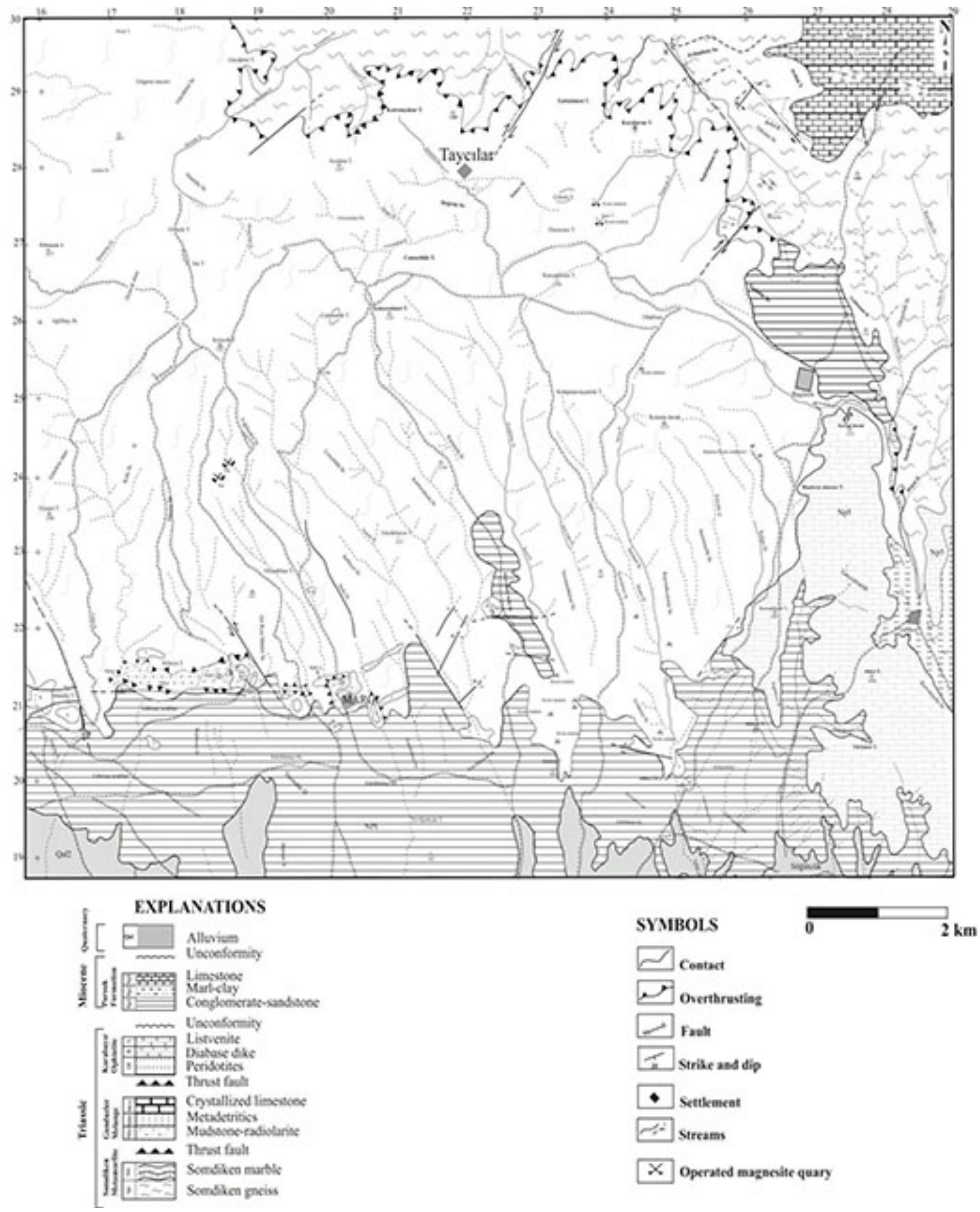

Figure 3. Geologic map of Marg1 area [30, 36] 

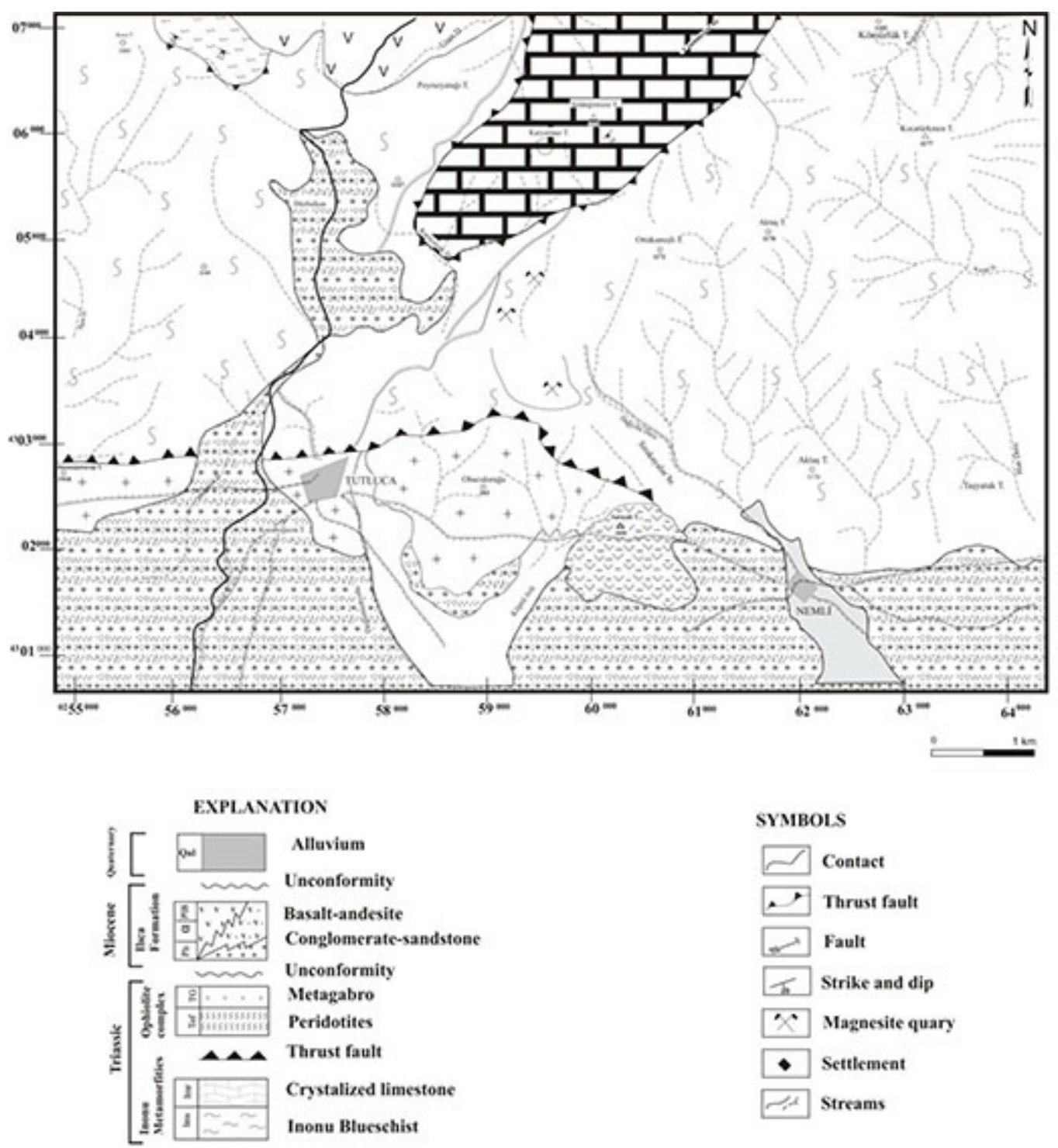

SYMBOLS

\begin{tabular}{|c|c|}
\hline$\pi$ & Contact \\
\hline r & Thrust fault \\
\hline & Fault \\
\hline 与 & Strike and dip \\
\hline$x$ & Magnesite quary \\
\hline 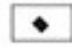 & Settlement \\
\hline-1 & Streams \\
\hline
\end{tabular}

Figure 4. Geologic map of Tutluca area [30, 36] 


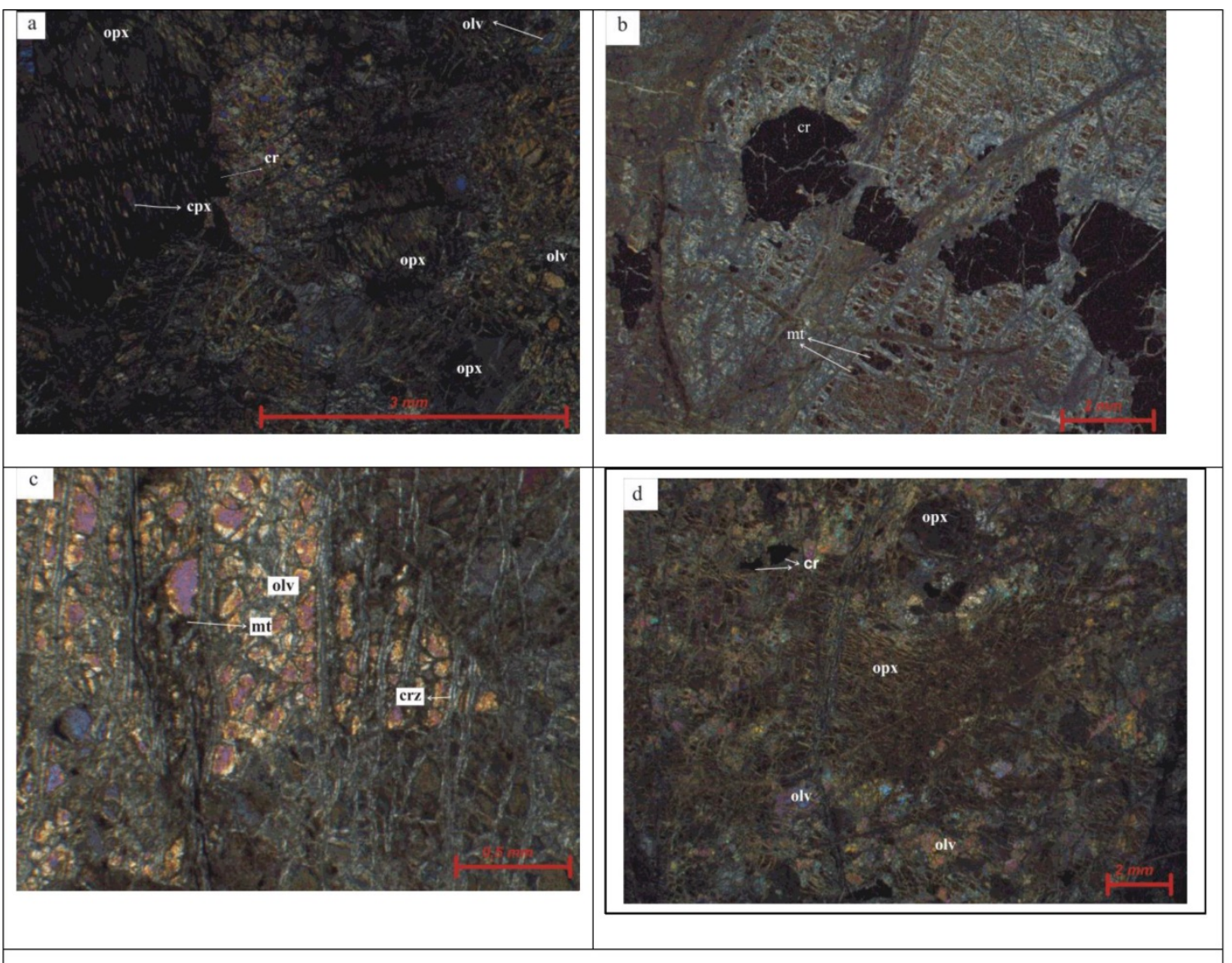

Figure 5. 4 photomicrographs of sepentizied harzburgite.

(mt: magnetite, crz: chrysotile, olv: olivine, opx: orthopyroxene, cr: chromite, cpx: clinopyroxene

a) Exsolution lamelle of orthopyroxene and iddingisite of olivine (Süleymaniye, crossed polars)

b) Chromite minerals of serpentinized dunite, cr: chromite, mt: magnetite (Tutluca, crossed polars)

c) Chrysotile and magnetite in olivine of serpentized harzburgite (crz: chrysotile, mt: magnetite, Margi, crossed polars)

d)Harzburgite of Tutluca cr: chromite, olv: olivine, opx: orthopyroxene (Tutluca, crossed polars) 


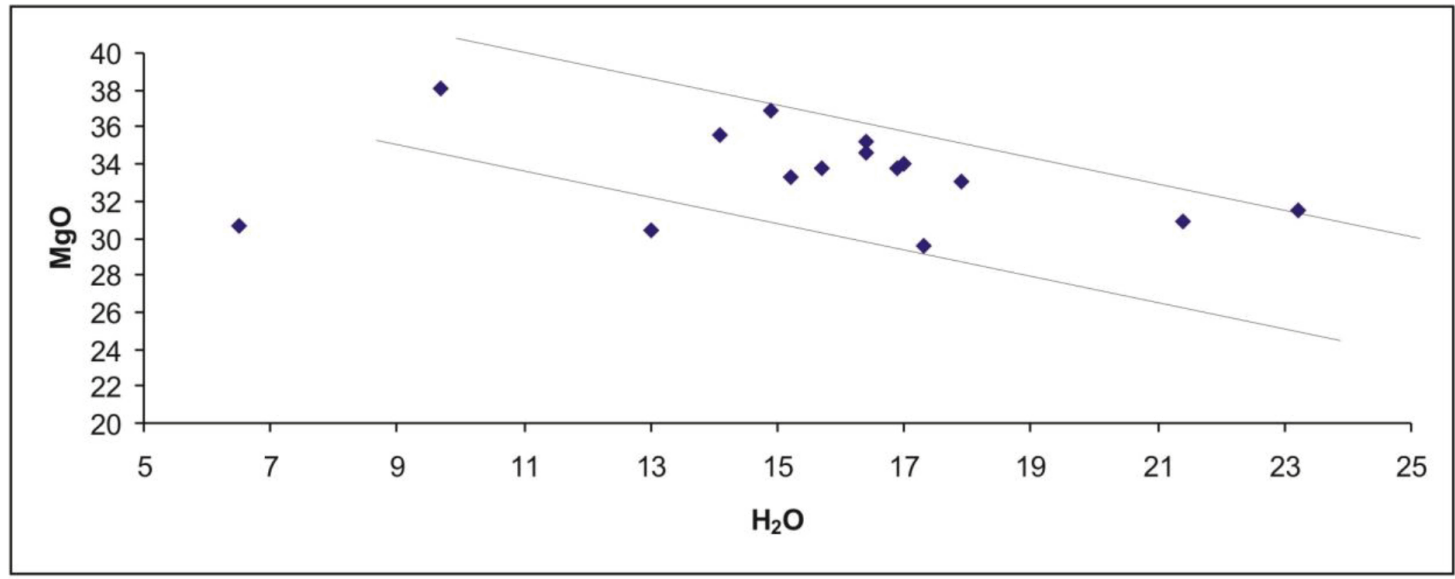

(b)

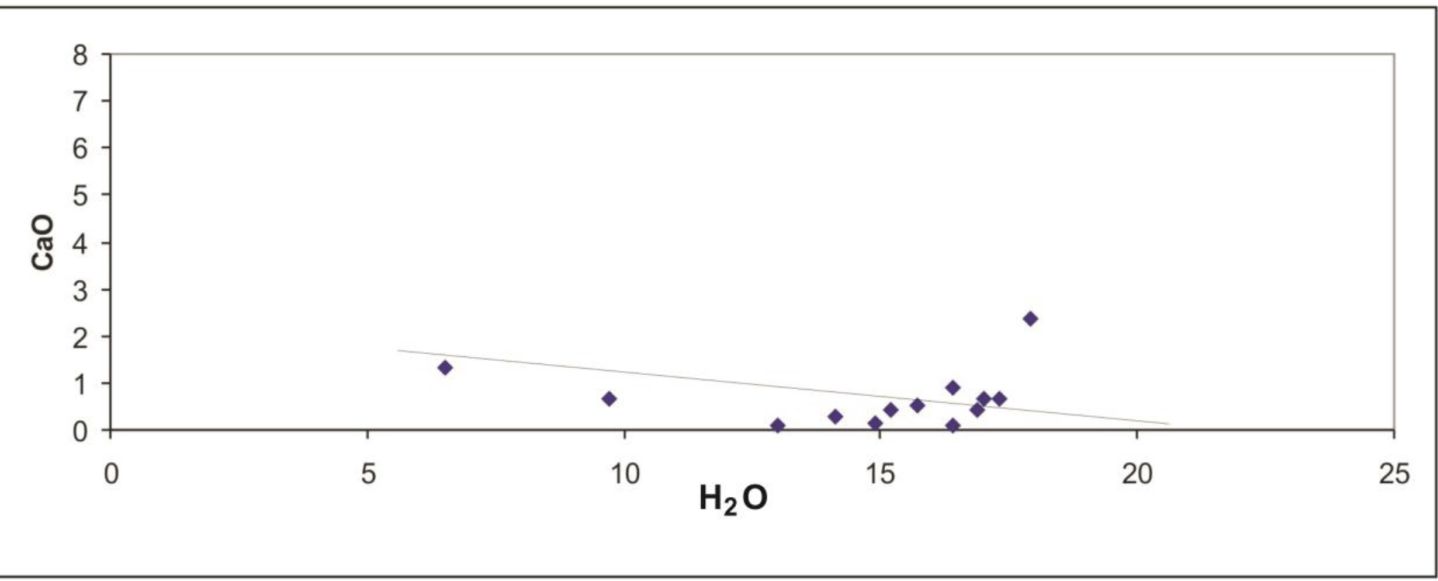

(c)

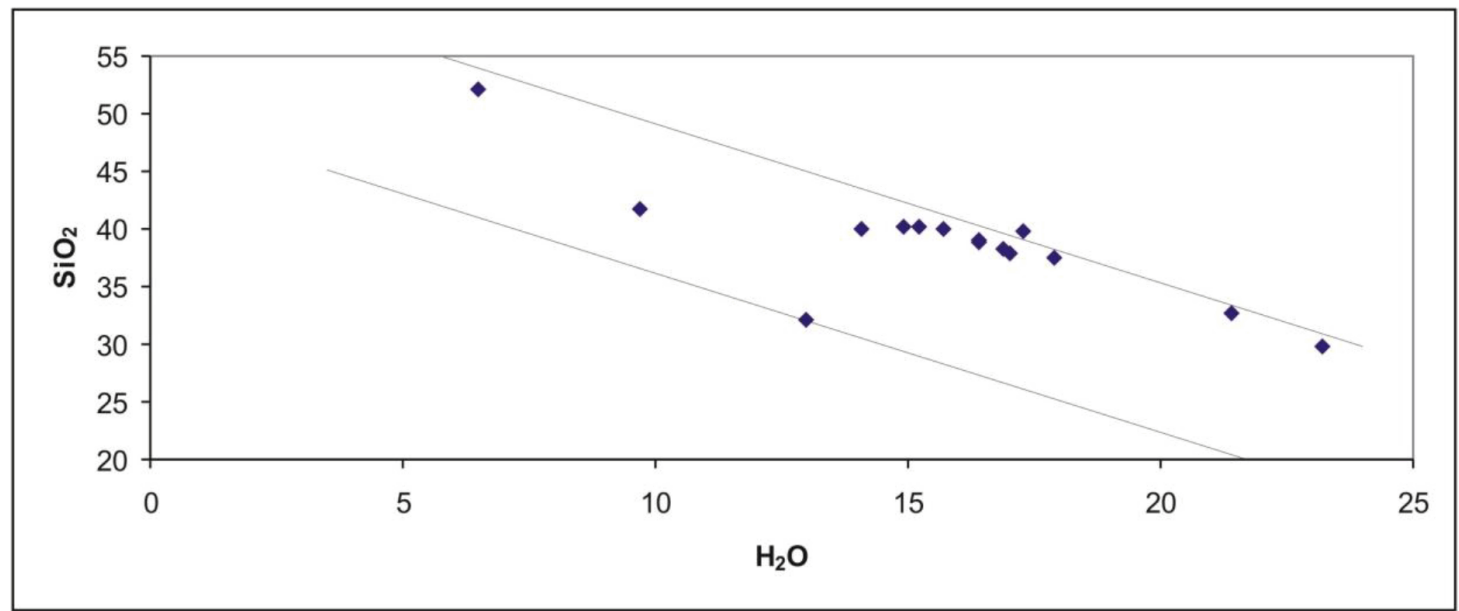

Figure 6. Relationship diagram between $\mathrm{MgO}, \mathrm{CaO}, \mathrm{SiO}_{2}$ with $\mathrm{H}_{2} \mathrm{O}$ 

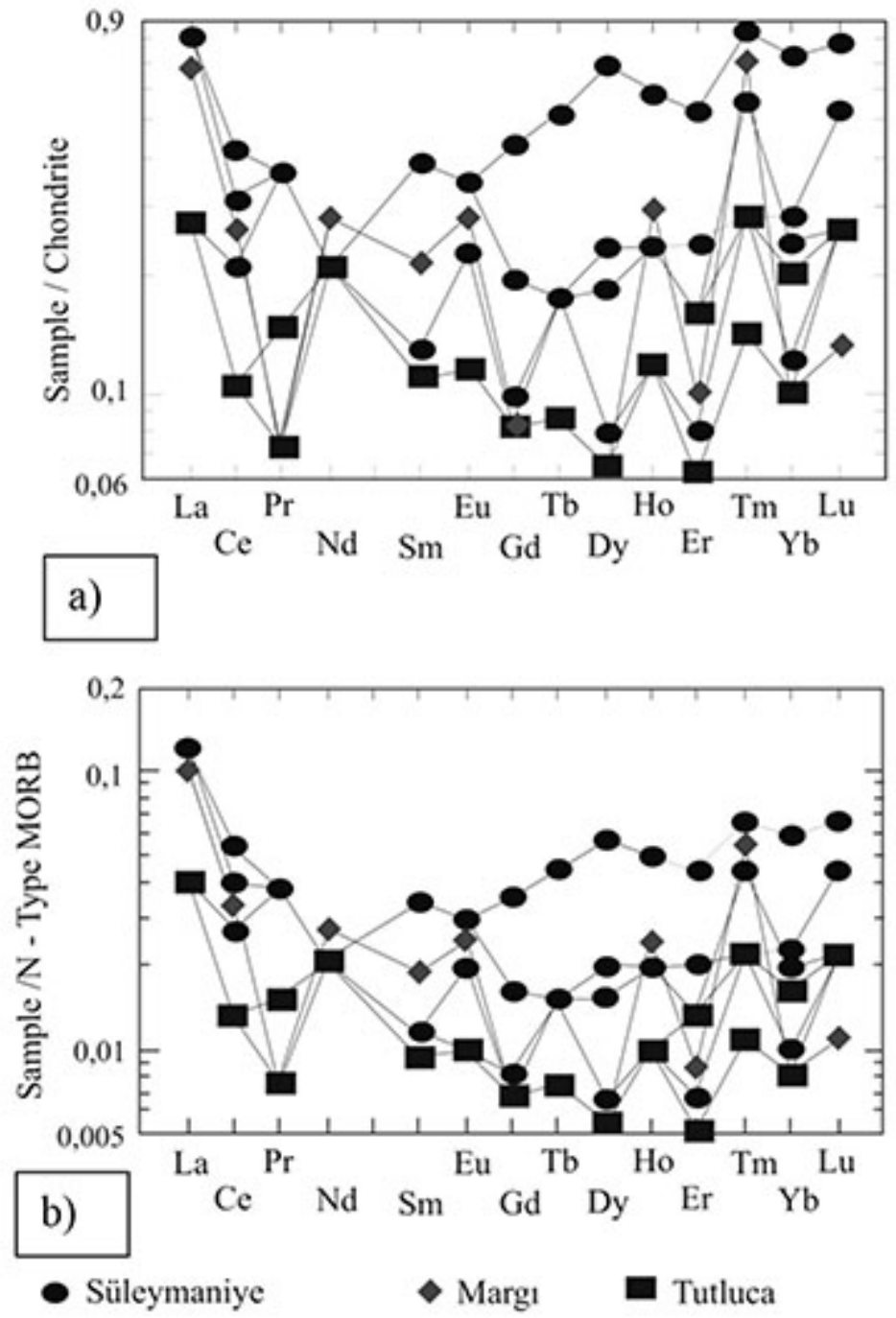

Figure 7. a) Chondrite normalized REE diagram pattern of the harzburgites, b) sample-N type MORB normalized REE of the harzburgites in the study area [49]. 


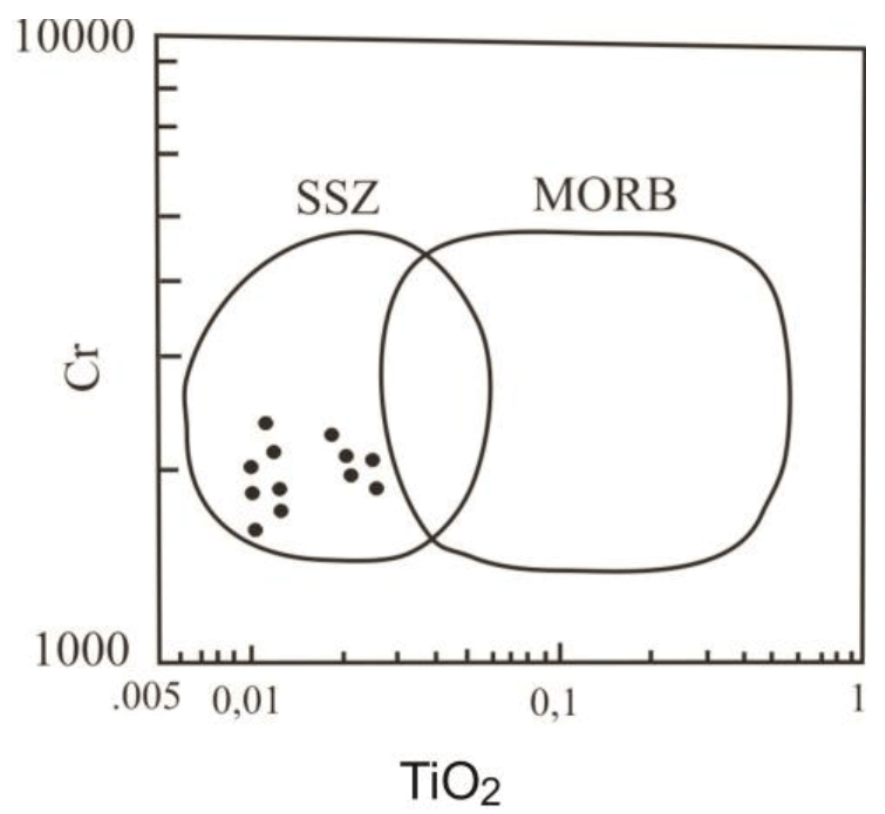

Figure 8. Cr versus $\mathrm{TiO} 2$, tectonic discrimination diagram [52].

Table 1. Major, trace and rare earth element data of serpentinites from the study areas (S: Süleymaniye köyü, M: Margı-Taycılar-Sepetci, T: Tutluca)

\begin{tabular}{|c|c|c|c|c|c|c|c|}
\hline Sample & SY1 & SY2 & SY3 & SY & M1Y & M4 & M6Y \\
\hline \multicolumn{8}{|c|}{ Major oxide elements (wt \%) } \\
\hline $\mathrm{SiO}_{2}$ & 38.18 & 39.74 & 32.76 & 40.01 & 38.93 & 32.17 & 29.80 \\
\hline $\mathrm{Al}_{2} \mathrm{O}_{3}$ & 0.11 & 2.00 & 1.04 & 1.83 & 0.35 & 3.05 & 0.21 \\
\hline $\mathrm{Fe}_{2} \mathrm{O}_{3 \text { tot }}$ & 9.65 & 9.60 & 7.64 & 7.27 & 8.14 & 8.71 & 6.82 \\
\hline $\mathrm{MgO}$ & 33.76 & 29.59 & 30.89 & 35.62 & 35.20 & 30.38 & 31.55 \\
\hline $\mathrm{CaO}$ & 0.43 & 0.66 & 5.36 & 0.27 & 0.08 & 0.10 & 7.58 \\
\hline $\mathrm{Na}_{2} \mathrm{O}$ & 0.01 & 0.05 & 0.04 & 0.01 & 0.02 & 0.01 & 0.02 \\
\hline $\mathrm{K}_{2} \mathrm{O}$ & 0.04 & 0.08 & 0.06 & $<0.04$ & $<0.04$ & $<0.04$ & $<0.04$ \\
\hline $\mathrm{TiO}_{2}$ & 0.01 & 0.03 & 0.02 & 0.03 & $<0.01$ & 0.05 & $<0.01$ \\
\hline $\mathrm{P}_{2} \mathrm{O}_{5}$ & 0.03 & 0.02 & 0.02 & 0.02 & $<0.01$ & $<0.01$ & $<0.01$ \\
\hline $\mathrm{MnO}$ & 0.11 & 0.07 & 0.10 & 0.08 & 0.08 & 0.10 & 0.08 \\
\hline $\mathrm{Cr}_{2} \mathrm{O}_{3}$ & 0.361 & 0.516 & 0.300 & 0.425 & 0.369 & 12.001 & 0.347 \\
\hline LOI & 16.9 & 17.3 & 21.4 & 14.1 & 16.4 & 13.0 & 23.2 \\
\hline \multicolumn{8}{|c|}{ Trace elements (ppm) } \\
\hline $\mathrm{Ni}$ & 2735 & 2157 & 1865 & 1944 & 2392 & 2454 & 2214 \\
\hline $\mathrm{Sc}$ & 4 & 12 & 9 & 11 & 7 & 8 & 6 \\
\hline $\mathrm{Ba}$ & 11.7 & 18.3 & 29.9 & 12.1 & 4.6 & 3.4 & 3.5 \\
\hline $\mathrm{Be}$ & $<1$ & $<1$ & $<1$ & $<1$ & $<1$ & $<1$ & $<1$ \\
\hline $\mathrm{Co}$ & 105.2 & 87.5 & 86.8 & 83.8 & 106.4 & 103.7 & 95.8 \\
\hline Cs & 0.2 & 13.2 & 0.2 & 0.9 & $<0.1$ & $<0.1$ & $<0.1$ \\
\hline $\mathrm{Ga}$ & 0.5 & 1.5 & 1.1 & 1.5 & $<0.5$ & 4.1 & $<0.5$ \\
\hline $\mathrm{Hf}$ & $<0.5$ & $<0.5$ & $<0.5$ & $<0.5$ & $<0.5$ & $<0.5$ & $<0.5$ \\
\hline $\mathrm{Nb}$ & $<0.5$ & 0.5 & $<0.5$ & $<0.5$ & $<0.5$ & $<0.5$ & $<0.5$ \\
\hline $\mathrm{Rb}$ & 0.5 & 3.8 & 2.0 & 0.6 & $<0.5$ & 0.8 & $<0.5$ \\
\hline $\mathrm{Sn}$ & $<1$ & $<1$ & $<1$ & $<1$ & $<1$ & $<1$ & $<1$ \\
\hline $\mathrm{Sr}$ & 30.4 & 20.6 & 499.9 & 19.7 & 1.7 & 2.0 & 27.4 \\
\hline $\mathrm{Ta}$ & $<0.1$ & 0.1 & 0.1 & $<0.1$ & $<0.1$ & $<0.1$ & $<0.1$ \\
\hline
\end{tabular}




\begin{tabular}{|c|c|c|c|c|c|c|c|}
\hline $\mathrm{Th}$ & $<0.1$ & $<0.1$ & $<0.1$ & 0.1 & $<0.1$ & $<0.1$ & $<0.1$ \\
\hline $\mathrm{U}$ & 1.8 & 0.8 & 1.2 & 0.1 & 3.6 & $<0.1$ & 0.2 \\
\hline $\mathrm{V}$ & 17 & 54 & 42 & 48 & 32 & 129 & 23 \\
\hline W & 0.3 & 0.7 & 0.3 & 0.1 & $<0.1$ & $<0.1$ & 0.2 \\
\hline $\mathrm{Zr}$ & 0.5 & 2.0 & 1.6 & 0.6 & $<0.5$ & $<0.5$ & $<0.5$ \\
\hline $\mathrm{Y}$ & 0.1 & 0.6 & 0.4 & 1.5 & $<0.1$ & $<0.1$ & $<0.1$ \\
\hline \multicolumn{8}{|c|}{ Rare earth elements (ppm) } \\
\hline $\mathrm{La}$ & 0.3 & 0.3 & 0.3 & 0.1 & $<0.5$ & $<0.5$ & $<0.5$ \\
\hline $\mathrm{Ce}$ & 0.3 & 0.4 & 0.3 & 0.2 & $<0.5$ & $<0.5$ & $<0.5$ \\
\hline $\operatorname{Pr}$ & 0.05 & 0.05 & 0.05 & 0.05 & $<0.02$ & $<0.02$ & $<0.02$ \\
\hline $\mathrm{Nd}$ & $<0.3$ & $<0.3$ & $<0.3$ & $<0.3$ & $<0.4$ & $<0.4$ & $<0.4$ \\
\hline $\mathrm{Sm}$ & $<.05$ & 0.09 & $<0.05$ & 0.09 & $<0.1$ & $<0.1$ & $<0.1$ \\
\hline $\mathrm{Eu}$ & $<0.02$ & 0.03 & 0.02 & 0.03 & $<0.05$ & $<0.05$ & $<0.05$ \\
\hline $\mathrm{Gd}$ & $<0.05$ & 0.06 & $<0.05$ & 0.13 & $<0.05$ & $<0.05$ & $<0.05$ \\
\hline $\mathrm{Tb}$ & 0.01 & 0.01 & 0.01 & 0.03 & $<0.01$ & 0.01 & $<0.01$ \\
\hline Dy & $<0.05$ & 0.09 & 0.07 & 0.26 & $<0.05$ & $<0.05$ & $<0.05$ \\
\hline Ho & $<0.02$ & 0.02 & 0.02 & 0.05 & $<0.05$ & $<0.05$ & $<0.05$ \\
\hline $\mathrm{Er}$ & $<0.03$ & 0.06 & 0.04 & 0.13 & $<0.05$ & $<0.05$ & $<0.05$ \\
\hline $\mathrm{Tm}$ & 0.01 & 0.01 & 0.02 & 0.03 & $<0.05$ & $<0.05$ & $<0.05$ \\
\hline $\mathrm{Yb}$ & $<0.05$ & 0.07 & 0.06 & 0.18 & $<0.05$ & $<0.05$ & $<0.05$ \\
\hline $\mathrm{Lu}$ & 0.01 & 0.02 & 0.01 & 0.03 & $<0.01$ & $<0.01$ & $<0.01$ \\
\hline
\end{tabular}

\begin{tabular}{|c|c|c|c|c|c|c|c|c|}
\hline Sample & M17Y & M18Y & $\mathrm{T} 4 \mathrm{Y}$ & $\mathrm{T} 1 \mathrm{Y}$ & $\mathrm{T} 2 \mathrm{Y}$ & $\mathrm{T} 3 \mathrm{Y}$ & T3Y1 & $\mathrm{T} 2 \mathrm{Y} 1$ \\
\hline \multicolumn{9}{|c|}{ Major oxide elements (wt \%) } \\
\hline $\mathrm{SiO}_{2}$ & 41.82 & 52.18 & 37.79 & 39.93 & 40.11 & 38.95 & 37.50 & 40.19 \\
\hline $\mathrm{Al}_{2} \mathrm{O}_{3}$ & 0.53 & 1.12 & 0.35 & 0.61 & 0.92 & 0.40 & 0.59 & 0.30 \\
\hline $\mathrm{Fe}_{2} \mathrm{O}_{3 \text { tot }}$ & 8.22 & 7.25 & 8.05 & 8.53 & 8.98 & 7.86 & 7.78 & 6.82 \\
\hline $\mathrm{MgO}$ & 38.13 & 30.71 & 34.00 & 33.79 & 33.33 & 34.61 & 33.05 & 36.88 \\
\hline $\mathrm{CaO}$ & 0.68 & 1.34 & 0.65 & 0.50 & 0.44 & 0.91 & 2.39 & 0.15 \\
\hline $\mathrm{Na}_{2} \mathrm{O}$ & 0.01 & $<0.01$ & 0.01 & 0.02 & 0.05 & 0.01 & 0.01 & 0.01 \\
\hline $\mathrm{K}_{2} \mathrm{O}$ & $<0.04$ & $<0.04$ & $<0.04$ & $<0.04$ & $<0.04$ & $<0.04$ & $<0.04$ & $<0.04$ \\
\hline $\mathrm{TiO}_{2}$ & $<0.01$ & 0.02 & $<0.01$ & $<0.01$ & $<0.01$ & $<0.01$ & $<0.01$ & $<0.01$ \\
\hline $\mathrm{P}_{2} \mathrm{O}_{5}$ & $<0.01$ & $<0.01$ & 0.02 & 0.01 & 0.03 & 0.03 & 0.03 & 0.02 \\
\hline $\mathrm{MnO}$ & 0.11 & 0.14 & 0.10 & 0.11 & 0.12 & 0.10 & 0.10 & 0.09 \\
\hline $\mathrm{Cr}_{2} \mathrm{O}_{3}$ & 0.402 & 0.498 & 1.553 & 0.413 & 0.428 & 0.382 & 0.312 & 0.258 \\
\hline LOI & 9.7 & 6.5 & 17.0 & 15.7 & 15.2 & 16.4 & 17.9 & 14.9 \\
\hline \multicolumn{9}{|c|}{ Trace elements (ppm) } \\
\hline $\mathrm{Ni}$ & 2364 & 1014 & 2781 & 2259 & 2344 & 2186 & 2049 & 2356 \\
\hline $\mathrm{Sc}$ & 11 & 18 & 5 & 9 & 11 & 7 & 9 & 3 \\
\hline $\mathrm{Ba}$ & 7.2 & 6.6 & 24.6 & 9.5 & 9.7 & 5.1 & 9.1 & 4.9 \\
\hline $\mathrm{Be}$ & $<1$ & $<1$ & $<1$ & $<1$ & $<1$ & $<1$ & $<1$ & $<1$ \\
\hline Co & 107.6 & 69.6 & 114.1 & 110.8 & 115.6 & 100.9 & 103.0 & 103.8 \\
\hline Cs & $<0.1$ & $<0.1$ & $<0.1$ & 0.1 & $<0.1$ & $<0.1$ & $<0.1$ & $<0.1$ \\
\hline $\mathrm{Ga}$ & 0.6 & 1.1 & 0.5 & 0.6 & 0.9 & $<0.5$ & 0.8 & 0.5 \\
\hline $\mathrm{Hf}$ & $<0.5$ & $<0.5$ & $<0.5$ & $<0.5$ & $<0.5$ & $<0.5$ & $<0.5$ & $<0.5$ \\
\hline $\mathrm{Nb}$ & $<0.5$ & $<0.5$ & $<0.5$ & $<0.5$ & $<0.5$ & $<0.5$ & $<0.5$ & $<0.5$ \\
\hline
\end{tabular}




\begin{tabular}{|c|c|c|c|c|c|c|c|c|}
\hline $\mathrm{Rb}$ & $<0.5$ & $<0.5$ & $<0.5$ & 0.5 & $<0.5$ & $<0.5$ & $<0.5$ & $<0.5$ \\
\hline $\mathrm{Sn}$ & $<1$ & $<1$ & $<1$ & $<1$ & $<1$ & $<1$ & $<1$ & $<1$ \\
\hline $\mathrm{Sr}$ & 1.5 & 2.8 & 5.6 & 2.5 & 3.5 & 6.4 & 20.5 & 1.6 \\
\hline $\mathrm{Ta}$ & $<0.1$ & $<0.1$ & $<0.1$ & $<0.1$ & $<0.1$ & $<0.1$ & $<0.1$ & $<0.1$ \\
\hline Th & $<0.1$ & $<0.1$ & $<0.1$ & $<0.1$ & $<0.1$ & $<0.1$ & $<0.1$ & $<0.1$ \\
\hline $\mathrm{U}$ & $<0.1$ & $<0.1$ & $<0.1$ & 0.1 & 0.9 & 0.7 & 0.3 & $<0.1$ \\
\hline V & 43 & 59 & 35 & 34 & 47 & 25 & 27 & 14 \\
\hline W & 0.2 & $<0.1$ & 0.1 & 0.1 & 0.1 & 0.1 & $<0.1$ & $<0.1$ \\
\hline $\mathrm{Zr}$ & $<0.5$ & $<0.5$ & $<0.5$ & $<0.5$ & $<0.5$ & $<0.5$ & $<0.5$ & 0.5 \\
\hline $\mathrm{Y}$ & $<0.1$ & 0.2 & $<0.1$ & 0.1 & 0.1 & 0.1 & 0.4 & 0.2 \\
\hline \multicolumn{9}{|c|}{ Rare earth elements (ppm) } \\
\hline $\mathrm{La}$ & $<0.5$ & $<0.5$ & $<0.5$ & 0.1 & $<0.1$ & $<0.1$ & $<0.1$ & $<0.1$ \\
\hline $\mathrm{Ce}$ & $<0.5$ & $<0.5$ & $<0.5$ & 0.1 & $<0.1$ & $<0.1$ & $<0.1$ & $<0.1$ \\
\hline $\operatorname{Pr}$ & $<0.02$ & $<0.02$ & $<0.02$ & $<0.02$ & $<0.02$ & $<0.02$ & $<0.02$ & $<0.02$ \\
\hline $\mathrm{Nd}$ & $<0.4$ & $<0.4$ & $<0.4$ & $<0.3$ & $<0.3$ & $<0.3$ & $<0.3$ & $<0.3$ \\
\hline $\mathrm{Sm}$ & $<0.1$ & $<0.1$ & $<0.1$ & $<0.05$ & $<0.05$ & $<0.05$ & $<0.05$ & $<0.05$ \\
\hline $\mathrm{Eu}$ & $<0.05$ & $<0.05$ & $<0.05$ & $<0.02$ & $<0.02$ & $<0.02$ & $<0.02$ & $<0.02$ \\
\hline $\mathrm{Gd}$ & $<0.05$ & $<0.05$ & $<0.05$ & $<0.05$ & $<0.05$ & $<0.05$ & $<0.05$ & $<0.05$ \\
\hline $\mathrm{Tb}$ & $<0.01$ & $<0.01$ & $<0.01$ & $<0.01$ & $<0.01$ & $<0.01$ & $<0.01$ & $<0.01$ \\
\hline Dy & $<0.05$ & $<0.05$ & $<0.05$ & $<0.05$ & $<0.05$ & $<0.05$ & $<0.05$ & $<0.05$ \\
\hline Ho & $<0.05$ & $<0.05$ & $<0.05$ & $<0.02$ & $<0.02$ & $<0.02$ & $<0.02$ & $<0.02$ \\
\hline $\mathrm{Er}$ & $<0.05$ & $<0.05$ & $<0.05$ & $<0.03$ & 0.04 & $<0.03$ & 0.04 & $<0.03$ \\
\hline $\mathrm{Tm}$ & $<0.05$ & $<0.05$ & $<0.05$ & $<0.01$ & 0.01 & $<0.01$ & 0.01 & $<0.01$ \\
\hline $\mathrm{Yb}$ & 0.06 & $<0.05$ & $<0.05$ & $<0.05$ & $<0.05$ & $<0.05$ & $<0.05$ & $<0.05$ \\
\hline $\mathrm{Lu}$ & $<0.01$ & $<0.01$ & $<0.01$ & 0.01 & 0.01 & $<0.01$ & 0.01 & $<0.01$ \\
\hline
\end{tabular}

\section{Acknowledgements}

This study that is part of the $\mathrm{PhD}$ research was supported by Scientific Research Project Coordination of Süleyman Demirel University (BAP Project No: 1076-D-5).

\section{REFERENCES}

[1] M.C. Goncuoğlu, and K. Tureli. Petrology and Geodynamic Interpretation of the Plagiogranites in the Central Anatolian Ophiolite (Aksaray-Turkey). Turkish Journal Earth Sci.2: 195-203, 1993.

[2] M.K. Yalınız, P.A. Floyd, and M.C. Göncüoğlu. Supra-Subduction Zone Ophiolites of Central Anatolia: Geochemical Evidence from the Sarıaraman Ophiolite, Aksaray, Turkey: Min. Mag., 60: 697-710, 1996.

[3] O. Tüysüz, A. Dellaloğlu, and N.Terzioğlu. A Magmatic Belt within the Neo-Tethyan Zone and its Role in the Tectonic Evolution of Northern Turkey. Tectonophysics, 243: 173-191, 1995.

[4] M.C. Göncöoğlu, K. Dirik, and H. Kozlu. General Characteristics of Pre-Alpine and Alpine terranes in Turkey:
Explanatory notes to the Terane map of Turkey. Ann. Geol. Pays Helen. 37: 515-536, 1997.

[5] A.I. Okay, and O. Tüysüz. Tethyan Sutures of Northern Turkey. In: B. Durand, L. Jolivet, E. Horvath and M. Serrane (Eds.), the Mediterranean Basins, Extension within the Alpine Orogen. Geological Society of London Special Publication, 156: 475-515, 1999.

[6] M.G. Barth, P.R.D. Mason, G.R. Davies, A.H. Dijkstra and M.R. Drury. Geochemistry of the Orthris ophiolite, Greece: Evidence for refertilization? J. Petrol., 44:1759-1785, 2003.

[7] N. Niu and R. He'kinian. Speading-rate dependence of the extent of mantle melting beneath ocean ridges. Nature, 385 : 326-329, 1997.

[8] J.A. Pearce, S.J. Lippard, and S. Roberts. Characteristics and tectonic significance of supra-subduction zone ophiolities. In: KOKELAAR, B.P.\&HOWELLS, M.F.(eds) Marginal Basin Geology. Geological Society, London, Special Publications, $16,77-89,1984$

[9] D.B. Wenner and H.P.Jr. Taylor. Temperatures of Serpentinization of Ultramafic Rocks Based on 18/O16 Fraktionation Between Coexisting Serpantine and Magnetite, Cont. Mineral. Petrol., 32, 165-185, 1971.

[10] R.S. Dietz. Ocean Basin Evolution by Sea-Floor Spreading, In "Continental Drift", S.K. Runcorn (Edit.), Academic Pres, 
New York, s. 289-98, 1962.

[11] H.H. Hess. History of Ocean Basins in Petrologic Studies, Buddington Volume, Geol.Soc. America, Colorado, p.599-620. 1962

[12] R.G. Coleman. Serpentinites, Rodingites, and Tectonic Inclusions in Alpine-type Mountain Chains. Geological Society of America, Special Papers;73,1963.

[13] I. Barnes, J.R. O'Neil. The relationship between fluids in some fresh alpine-type ultramafics and possible modern serpentinization. Geological Society of America Bulletin: 80: 1947-1960, 1969.

[14] B.R. Frost.On the stability of sulfides, oxides, and native metals in serpentinite. Journal of Petrology: 26: 31-63. 1985

[15] T.A. Abrajano, N.C. Sturchio, J.K. Bohlke, G.L. Lyon, R.J. Poreda, C.M. Stevens. Methane-hydrogen seeps, Zambales Ophiolite, Philippines: Deep or shallow origin? Chemical Geology; 71: 211-222. 1988.

[16] A. Peretti, J. Dubessy, J. Mullis, B.R. Frost, V. Trommsdorff Highly reducing conditions during Alpine metamorphism of the Malenco peridotite (Sondrio, northern Italy) indicated by mineral paragenesis and $\mathrm{H}_{2}$ in fluid inclusions,. Contributions to Mineralogy and Petrology;112: 329-340, 1992.

[17] O. Muntener, J. Hermann. Titanian andradite in a metapyroxenite layer from the Malenco ultramafics (Italy): implications for Ti-mobility and low oxygen fugacity. Contributions to Mineralogy and Petrology;116:156-168, 1994.

[18] J.L. Charlou, Y. Fouquet, H. Bougault, J.P. Donval, J. Etoubleau, P. Jean-Baptiste, A. Dapoigny, P. Appriou, P.A. Rona. Intense $\mathrm{CH}_{4}$ plumes generated by serpentinization of ultramafic rocks at the intersection of the $15^{\circ} 20^{\prime} \mathrm{N}$ fracture zone and the Mid-Atlantic Ridge. Geochimica et Cosmochimica Acta;62: 2323-2333, 1998.

[19] J.L. Charlou, J.P. Donval, Y. Fouquet, P. Jean-Baptiste, N. Holm. Geochemistry of high $\mathrm{H}_{2}$ and $\mathrm{CH}_{4}$ vent fluids issuing from ultramafic rocks at the Rainbow hydrothermal field, (36²14'N, MAR). Chemical Geology;191:345-359, 2002.

[20] J.S. Beard, L. Hopkinson. A fossil, serpentinization-related hydrothermal vent, Ocean Drilling Program Leg 173, Site 1068 (Iberia Abyssal Plain): Some aspects of mineral and fluid chemistry. Journal of Geophysical Research; 105: 16527-16540, 2000.

[21] D.E. Allen, W.E. Seyfried. Compositional controls on vent fluids from ultramafic-hosted hydrothermal systems at midocean ridges: An experimental study at $400^{\circ} \mathrm{C}, 500$ bars. Geochimica et Cosmochimica Acta; 67: 1531-1542, 2003.

[22] M.J. Mottl, C.G. Wheat, P. Fryer, J. Gharib, J.B. Martin.Chemistry of springs across the Mariana forearc shows progressive devolatilization of the subducting plate. Geochimica et Cosmochimica Acta;68: 4915-4933, 2004.

[23] J.L. Palandri, M.H. Reed.Geochemical models of metasomatism in ultramafic systems: Serpentinization, rodingitization, and sea floor carbonate chimney precipitation. Geochimica et Cosmochimica Acta; 68: 1115-1133, 2004.

[24] J.W. Shervais, P. Kolesar, K. Andreasen. A field and chemical study of serpentinization-Stonyford, California: chemical flux and mass balance. International Geology Review; 47: 1-28, 2005.

[25] B.R. Frost, J.S. Beard. On silica activity and serpentinization. Journal of Petrology;48: 1351-1368, 2007.

[26] K, Bucher, and M. Frey. Petrogenesis of Metamorphic Rocks $6^{\text {th }}$ Edition Complete Revision of Winkler's Textbook, Springer-Verlag Berlin Heidelberg New York, 144-169, 1994.

[27] D.S. O'Hanley. Serpantinites: Records of Tectonic and Petrological History, Oxford Monographs on Geology and Geophysics, No: 34, 277p, New York, 1996.

[28] J.B. Moody. Serpantinization: A review, Lithos, 9, 125-138, 1976.

[29] R. Brinkmann. Geotektonicsfae Gllederung Von WestanatoHen: N.Jb. Geol. Palaeont Mh.603-618, 1966.

[30] A. Kahya, M. Kuşcu. Source of the mineralizing fluid in ultramafic related magnesite in the Eskişehir area, northwest Turkey, along the İzmir-Ankara Suture: a stable isotope study. Turkish Journal Earth Sci 23:1-15. 2014

[31] M.C.Goncuoğlu, M.K. Yalınız, U.K. Tekin. Geochemistry, Tectono-Magmatic Discrimination and Radiolarian Ages of Basic Extrusives within the İzmir-Ankara Suture Belt (NW Turkey): Time Constraints Fort He Neotehtyan Evolution., Ofiyoliti, 31(1), 25-38, 2006.

[32] N.B.W. Harris, S.P. Kelley and A.I. Okay. Post-collision Magmatism and Tectonics in Northwest Turkey. Contribution to Mineralogy and Petrology, 117, 241-252, 1994.

[33] A.P. Önen. Neotethyan Ophiolitic Rocks of the Anatolides of NW Turkey and Comparision with Tauride Ophiolites. J. Geol. Soc. London, 160: 947-962, 2003.

[34] E. Gökten, N. Kazancı, C. Acar. Ankara kuzeybatısında (Bağlum-Kazan arası) Geç Kretase-Pliyosen serilerinin stratigrafisi ve tektoniği. MTA Dergi 108: 69-81 (in Turkish), 1988.

[35] E. Gökten, P.A. Floyd. Stratigraphy and Geochemistry of Pillow Basalts within the Ophiolitic Melange of the İzmir-Ankara-Erzincan Suture Zone: İmplications fort the Geotectonic Character of the Northern Branc of Neotethys. Int J Earth Sci (Geol Rundsch). DOI 10.1007/s00531-006-01 32-4, 2006.

[36] M.Z. Gözler, F. Cevher, E. Ergul, H.J. Asutay. Orta Sakarya ve Güneyinin Jeolojisi [Geology of Central and Southern Sakarya Region]. Maden Tetkik ve Arama Genel Müdürlügüu Report No: 9937 (unpublished, in Turkish), 1997.

[37] K. Senturk, C. Karaköse. Geology of Middle Sakarya: Genel Müdürlüğü Derleme Rapor No: 6642, Ankara, 1979.

[38] A.L. Streckeisen. Classification and nomenclature of igneous rocks (Final report of an inquiry.) Neues Jahrbuch fur Mineralogie, Abhandlungen, 107,144-240, 1976.

[39] E.J. Olsen. Equilibrium calculations in the system $\mathrm{Mg}, \mathrm{Fe}, \mathrm{Si}$, O, H and Ni. American Journal Sci., 261, 943-956, 1963.

[40] B.W. Evans. Control of the products of serpentinization by the $\mathrm{Fe}^{2+} \mathrm{Mg}_{-1}$ exchange potential of olivine and orthopyroxene. Journal of Petrology; 49: 1873-1887, 2008. 
[41] P.B. Toft, J. Arkanai-Hamed, S.E. Haggerty. The effects of serpentinization on density and magnetic susceptibility: a petrophysical model. Physics of the Earth and Planetary Interiors; 65: 137-157. 1990.

[42] J.S. Beard, B.R. Frost, P. Fryer, A. McCaig, R. Searle, B. Ildefonse, P. Zinin, and S.K. Sharma. Onset and progress of serpentinization and magnetite formation in olivine-rich troctolites from IODP Hole U1309D: Journal of Petrology, v. 50, p. 387-403. 2009.

[43] Y.Z. Özkan. Guleman ofiyolitlerinde metamorfizma etkileri. MTA Dergisi, 101/102, 48-58. 1985.

[44] S.M. Swapp and B.R. Frost. Role of Silica Activity Controlling the Formation of Magnetite in Serpentinites: Evidence from Weakly Serpentinized Harzburgite from New Caledonia, Geological Society of America Abstracts with Programs, Vol. 40, No. 6, p. 452, 2008.

[45] K. Frieder, B. Wolfgang, J. Niels, M.Tom, M. Bruce, B. Thelma.. Iron partitioning and hydrogen generation during serpentinization of abyssal peridotites from $15^{\circ} \mathrm{N}$ on the Mid-Atlantic Ridge, Geochimica et cosmochimica acta, vol. 73, no.22, pp. 6868-6893, 2009.

[46] G.E. Brugmann, N.T. Arndt, A.W Hoffmann, H.J. Tobschall. Noble metal abundances in komatiite suites from Alexo, Ontario And Gorgona Island, Colombia, Geochim, Cosmochim. Acta, Vol. 51, Pp. 2159-2169, 1987.

[47] S.S. Sun, and R.W. Nesbit. Petrogenesis of Archean ultrabasic and basic volcanics: evidence from rare earth elements. Contribution Mineral Petrol. 65:301-325, 1978.

[48] F.B. Henderson. Hydrothermal Alteration and Ore Deposition in Serpentinite-Type Mercury Deposits. Economic Geology, v. 64:489-499, 1969.

[49] S.s. Sun and W.F. Donough. Chemical and isotopic systematics of oceanic basalts: implication for mantle composition and processes, In: A.D. Saunders and M.J. Norry (Editors), Magmatism in the Ocean Basins Geological Society, Londan, pp. 313-345, 1989.
[50] F.A. Fryer. Rare Earth Elementh Abundance in Upper Mantle Rocks, 'Handbook Rare Earth Element Geochemistry', Department of Mineralogy, Elsevier, vol.5, pp.153-203, 1984.

[51] O. Elitok. Geochemistry and tectonic significance of the Şarkikaraağaç Ophiolite in the Beyşehir-Hoyran nappes. SW Turkey, 4th International Symposium on Eastern Mediterranean Geology, 21-25 May, Isparta, p.181-196, 2001.

[52] J.A. Pearce. Role of the sub-continental lithosphere in magma genesis at active continental margins. In Continental Basalts and Mantle Xenoliths (C.J. Hawkesworth \& M.J. Norry, eds.). Shiva Press, Nantwich, U.K. (230-249), 1983.

[53] H. Sarp. Etude Geologiue Et Mine'ralogie Du Corteg'e Ophiolitique De I'a Re'gion Situeu Au NW de Yeşilova (Burdur, Turquie), The'se Univ. Gene've, 373p, 1976.

[54] R.G. Coleman, T.E. Keith. A chemical study of serpentinization - Burro Mountain, California. Journal of Petrology 12, 311-328, 1971.

[55] B.W. Evans, W. Johannes, H. Oterdoom, and V. Trommsdorff. Stability of Chrysotile and Antigorite in the Serpantine Multisystem, Schweiz. Mineral. Petrogr. Mitt.56, 79-93, 1976.

[56] J.A. Maltman. Serpentinite textures in Aglesey, North Wales, United Kingdom, Geol. Soc. of Am. Bull. V.89, 972 - 980 (Doc. No: 80702), 1978.

[57] J.S. Beard, R. Frost, F. Patricia, M.C. Andrew, S. Roger, B. Ildense, P.Zının and S.K.Sharma Sharma. Onset and Progression of Serpentinization and Magnetite Formation in Olivine-rich Troctolite from IODP Hole U1309D. Journal of Petrology, Volume 50, Issue 3, pp. 387-403, 2009.

[58] M. Wilson. Igneous Petrogenesis: A Global Tectonic Approach. Unwin Hyman, London, 466 pp, 1989.

[59] A. Ucurum. Listvenites in Turkey: Perspectives on Formation and Precious Metal Concentration with Reference to Occurrences in East-Central Anatolia. Ofioliti, 25 (1), 15-29, 2000 . 